\title{
Selectivity Criterion in State Aid Control
}

\author{
JAKUB KOCIUBIŃSKI*
}

\section{INTRODUCTION}

The creation and development of the Internal Market has spurred competition and allows for businesses to expand in size to become European players, increasing further economic growth. ${ }^{1}$ Modern European economies rely heavily on markets and private undertakings to decide what goods to sell, what markets to expand into, what R\&D to undertake and so on. The underlying principle is that free competition based on equal and nondiscriminatory treatment of every undertaking will ensure optimal economic efficiency. ${ }^{2}$ However, an uneven playing field may result from aid that Member States grant to companies operating in their territories. These measures may aim to support national champions, attract investments to their territory, etc. ${ }^{3}$ Even when the intentions of public authorities are most laudable, such policies may obstruct the process of economic growth and could lead to market fragmentation, which, in effect, would harm the overall competitiveness of the European Union's economy. ${ }^{4}$ State Aid control is thus a vital tool which complements the Internal Market's rules. ${ }^{5}$

Exercising effective State Aid control is by no means an easy task, considering the size of the Internal Market and the differences in social and

\section{DOI: 10.2478/wrlae-2013-0016}

* PhD, LLM; Assistant Professor; University of Wroclaw, Department of International and European Law; kociubinski.jakub@prawo.uni.wroc.pl

1 Jaques Derenne and Massimo Merola (eds), Economic Analysis of State Aid Rules Contributions and Limits (Lexxion 2007).

${ }^{2}$ This principle is based on the belief that competitive markets are an important protector of liberty. Daniel Yergin, Joseph Stanislaw, The Commanding Heights: The Battle for the World Economy (Simon \& Schuster 2002) 16.

3 See Neelie Kroes, 'Industrial Policy and Competition Law \& Policy', Speech at the Fordham University School of Law, New York, 14.09.2006 (IP Press Relase SPEECH/06/499). The former Competition Commissioner pointed out that previous experience of supporting national champions shows that results are counterproductive in terms of success in the global economy. Nevertheless, these kinds of policies are widespread among Member States.

4 These strategies are often described as 'beggar-thy-neighbour', which means a State's remedies for its own economic problems tend to have a negative impact on the economic situation of other States. See Kenneth A Reinert, Ramkishen S Rajan and Amy Jocelyn Glass (eds), The Princeton Encyclopaedia of the World Economy. Volume I: A - H(Princeton 2009) 126.

${ }^{5}$ Hans W Friederiszick, Lars-Hendrik Röller and Vincent Verouden, 'EC State Aid Control: an Economic Perspective' in Michael Sánchez Rydelski (ed), The EC State Aid Regime Distortive Effects of State Aid on Competition and Trade (Cameron May 2007) 145. 
economic development of the present 27 Member States. ${ }^{6}$ Furthermore, there is no legal definition of State Aid, although in European Court of Justice (ECJ) case-law the notion of aid is based on the actual wording of Article 107(1) of the Treaty on the Functioning of the European Union (TFEU). ${ }^{7}$ In practice, however, the ECJ has not adhered rigidly to that formulation. ${ }^{8}$ For the purposes of this paper, based on a synthesis of the Court's interpretations, in order to fall within Article 107 TFEU a State measure must be aid in a sense of a benefit of advantage ${ }^{9}$, must be granted by the State and/or through State resources ${ }^{10}$, must be of a selective nature, which means it must favour a certain undertaking or the production of certain goods ${ }^{11}$, and finally must

${ }^{6}$ Nicola Pesaresi and Marc Van Hoof, 'State Aid Control: An Introduction' in Wolfgang Mederer, Nicola Pesaresi and Marc Van Hoof (eds) EU Competition Law. Volume IV. State Aid, Book One (Claeys \& Casteels 2008) 4.

${ }^{7}$ Martino Ebner and Edoardo Gambaro, 'The Notion of State Aid' in Alberto Santa Maria (ed), Competition and State Aid. An Analysis of the EC Practice (Kluwer Law International 2008) 18. The Treaty on the Functioning of the European Union [2010] OJ L83/47. Subsequent citation of TFEU from this source. The wording of the provision has not changed since its adoption and therefore the current article number will be used in this paper unless in citation. Regarding European Courts' names during subsequent citations, their names at the time of delivering the relevant judgment will be used.

${ }^{8}$ Kelyn Bacon (ed), European Community Law of State Aid (OUP 2009), para 2.02. In doctrine, various sets of criteria are emphasized (See inter alia Aleksander Cieśliński, Wspólnotowe prawo gospodarcze. Tom 2 (C. H. Beck 2007) 519; Paweł Paradowski, 'Prawo pomocy publicznej dla przedsiębiorców' in Zbigniew Brodecki (ed), Konkurencja (Lexis Nexis 2004) 326; Igor Postuła, Aleksander Werner, Pomoc publiczna (Lexis Nexis 2006) 25; Tadeusz Skoczny, 'Zakaz antykonkurencyjnej pomocy państwa' in Jan Barcz (ed), Prawo Unii Europejskiej. Prawo materialne i polityki. Tom 2 (Prawo i Praktyka Gospodarcza 2005) II-421), however, it is ECJ case law and Commission decisions that serve as primary sources of definitions.

${ }^{9}$ See inter alia Cases C-256/97 Déménagements-Manutention Transport SA (DMT) [1999] ECR I-3913. Also Case C-256/97 DMT, Opinion of AG Jacobs, para 31. Case C-39/94 Syndicat français de l'Express international (SFEI) and others $v$ La Poste and Others [1996] ECR I-3547; C-39/94 SFEI Opinion of AG Jacobs, para 60; Cases 173/73, Italy v Commission [1974] ECR 709, para 26; C-387/92 Banco de Crédito Industrial SA, now Banco Exterior de España SA v Ayuntamiento de Valencia [1994] ECR I-877, paras 12 and 13; C280/00 Altmark Trans GmbH and Regierungspräsidium Magdeburg $v$ Nahverkehrsgesellschaft Altmark GmbH, and Oberbundesanwalt beim Bundesverwaltungsgericht [2003] ECR I-7747; T-157/01 Danske Busvognmond v Commission of the European Communities (Combus) [2004] ECR II-917, para 57.

${ }^{10}$ See inter alia Cases T-214/95 Het Vlaamse Gewest (Flemish Region) v Commission of the European Communities [1998] ECR II-717; 323/82 SA Intermills $v$ Commission of the European Communities [1984] ECR 3809; Joined Cases 296 and 318/82 Netherlands and Leeuwarder Papierwarenfabriek BV v Commission of the European Communities [1985] ECR I-809; C-142/87 Belgium v Commission of the European Communities (Tubemeuse) [1990] ECR I-959; C-303/88 Italy v Commission of the European Communities [1991] ECR I-1433; C-305/89 Italy v Commission of the European Communities [1991] ECR I-1603; C63/87 Commission of the European Communities v Greece [1988] ECR I-2875; C-102/87 France $v$ Commission of the European Communities (Fonds industriel de modernisation) [1988] ECR I-4067; Joined Cases C-15/98 and C-105/99 Italy and Sardegna Lines - Servizi Marittimi della Sardegna SpA v Commission of the European Communities [2000] ECR I8855.

${ }^{11}$ See inter alia Cases C-143/99 Adria-Wien Pipeline GmbH and Wietersdorfer \& Peggauer Zementwerke GmbH v Finanzlandesdirektion für Kärnten [2001] ECR I-8365; T-55/99 Confederación Española de Transporte de Mercancias (CETM) $v$ Commission of the European Communities [2000] ECR II-3207; C-200/97 Ecotrade Srl v Altiforni e Ferriere di Servola SpA (AFS) [1998] ECR I-7907, para 36; C-290/87 Netherlands v Commission of the European Communities (Fisheries quotas) [1989] ECR I-3083, paras 22-23; C-61/79 
actually or potentially be harmful to competition and trade between Member States. ${ }^{12}$ A lack of negative impact on trade or competition precludes a measure from being considered aid. ${ }^{13}$ The abovementioned conditions are cumulative. ${ }^{14}$ State Aid thus identified is in principle prohibited. ${ }^{15}$

Also, for the purpose of further analysis one must take into account that the legal concept of State Aid has an objective nature, which must be interpreted on the basis of objective factors. ${ }^{16}$ In other words, the provision does not distinguish between States' measures by reference to their cause or aims, but defines them in relation to their effects. ${ }^{17}$

Despite extensive but rather erratic case-law on the subject, the selectivity test is arguably the most difficult to apply. This is because not every measure that produces advantage for certain undertakings over others will fall within Article 107(1) TFEU. This paper will seek to place the selectivity criterion and its interpretation in service of one of the fundamental goals of the Internal Market - safeguarding competition and preventing subsidy races between Member States. ${ }^{18}$

Amministrazione delle finanze dello Stato v Denkavit italiana Srl [1980] ECR I-1205, para 31; T-260/97 R Camar v Commission of the European Communities and Council [1997] ECR II-2357, para 62 .

12 These conditions are usually treated together. See inter alia Joined Cases T-298/97, T312/97, T-313/97, T-315/97, T-600/97 to T-607/97, T-1/98, T-3/98 to T-6/98 and T-23/98 Alzetta Mauro and Others v Commission of the European Communities [2000] ECR II-2319, para 81 and Case T-288/97 Regione Friuli Venezia Giulia $v$ Commission of the European Communities [2001] ECR II-1169, para 41.

${ }^{13}$ Kazimierz Strzyczkowski, Prawo gospodarcze publiczne (Lexis Nexis 2007) 371.

Marek Szydło, 'Pojęcie pomocy państwa w prawie wspólnotowym' (2002) 4 Studia Europejskie 34. It must be noted that in ruling 730/79 Philip Morris Holland BV $v$ Commission of the European Communities [1980] ECR 2671 the Court held that any State measure which grant advantage to an undertaking (provided it could not be justified under Article 107(2) and (3) TFEU or under the 'escape clause' from Article 106(2) TFEU) will automatically be deemed incompatible with the Internal Market.

14 European Commission, XXVIth Report on Competition Policy 1996 (Brussels/Luxembourg 1997) 31.

${ }^{15}$ Article 107(1) TFEU uses the phrase 'incompatible with the Internal Market' instead of 'prohibited'. However, in the Steinke ruling the ECJ held that this article should be interpreted to contain a prohibition (C-78/76 Steinike \& Weinlig $v$ Federal Republic of Germany [1977] ECR I-595). Moreover, Member States are obliged to take every appropriate measure to achieve goals of the European Union. The Internal Market is one of these goals, and thus any measure that would obstruct its achievement is prohibited (Andrew Evans, Community Law of State Aids (Clarendon Press 1997) 2; Sławomir Dudzik, 'Bezpośrednia skuteczność przepisów prawa wspólnotowego dotyczących pomocy państwa dla przedsiębiorstw’ (2000) 7 PiP 41.

${ }^{16}$ Friederiszick, Röller and Verouden (n 5) 632; C-83/98 P France v Ladbroke Racing Ltd and Commission of the European Communities [2000] ECR I-3271, para 25; T-98/00 Linde $A G v$ Commission of the European Communities [2002] ECR II-3961, para 40; T-152/99 Hijos de Andrés Molina SA (HAMSA) v Commission of the European Communities [2002] ECR II-3049, para 159.

17 C-173/73 Italy $v$ Commission (n 9), para 13; C-56/93 Belgium $v$ Commission of the European Communities [1996] ECR I-723, para 79 C-75/97 Belgium v Commission of the European Communities (Maribel bis/ter) [1999] ECR I-3671, para 25; C-172/03 Wolfgang Heiser v Finanzamt Innsbruck [2005] ECR I-1627, para 46. Therefore, there is no room for any Member State's discretion T-67/94 Ladbroke Racing Ltd v Commission of the European Communities [1988] ECR II-01, para 52.

${ }^{18}$ See Lorenzo Coppi 'The Role of the State Aid Analysis and the Balancing Test' in Erika Szyszczak (ed) Research Handbook on European State Aid Law (Edward Elgar 2011) 76. 


\section{CONSTRUCTION AND RATIONALE OF THE SELECTIVITY CRITERION}

The following provision of Article 107(1) TFEU, “(...) favouring of certain undertakings or the production of certain goods (...)", is commonly referred to as the notion of selectivity. ${ }^{19}$ The raison d'etre of this condition is to avoid an enquiry into the entire legislative system of the Member States by reference to rules applicable in other States. ${ }^{20}$ In other words, the selectivity criterion serves as a yardstick which enables distinguishing between national measures that may distort the Internal Market and need to be addressed by EU legislation and those that fall under the State Aid control regime. ${ }^{21}$ As Advocate General Nial Fennelly correctly observed in Ecotrade, "the alternative would imply a generalised review of all State regulation (...) by reference to the yardstick, not of the normally applicable rules in that State (...), but, presumably, of the regulations in the other Member States." 22 The Advocate General concluded that "this would be counter-productive, by penalising those States whose general economic organisation and regulation was the most competitive". ${ }^{23}$

As a point of departure, one must note that there is no legal definition of 'general' or 'selective' measures in acquis communautaire. ${ }^{24}$ While the notion of 'selectivity' is largely based on the wording of Article 107(1) TFEU, then, a contrario with reference to 'apparently general' measures one must indicate that the aid is not aimed at one or more specific recipients defined in advance, but rather subject to a series of objective criteria pursuant to which it may be granted to a potentially indefinite number of operators who are not exhaustively identified. ${ }^{25}$ It is then a measure that serves the whole economy, effective on the entire territory of a given Member State, and is applicable to all undertakings in all sectors. ${ }^{26}$

As a rule of thumb, a measure in question is hence selective if it produces advantages exclusively for certain undertakings or certain sectors. ${ }^{27}$ To determine that, it is necessary to establish a point of reference for

\footnotetext{
${ }^{19}$ Andreas Bartosch, 'Is there a need for a rule of reason in European State Aid law?: Or how to arrive at a coherent concept of material selectivity?' (2010) 47 CMLR 729.

20 ibid.

${ }^{21}$ Pesaresi and Van Hoof (n 6) 7.

${ }^{22}$ C-200/97 Ecotrade (n 11), Opinion of AG Fennelly, para 25.

23 ibid.

24 Phaedon Nicolaides, Mihalis Kekelekis and Philip Buyskes, State Aid Policy in the European Community: A Guide for Practicioners (Kluwer Law International 2005) 25.

${ }^{25}$ Ebner and Gambaro (n 7) 27. Andrea Biondi, Piet Eeckhout, James Flynn (eds) The Law of State Aids in the European Union (OUP 2004) 3. It is worth mentioning that the ECJ hardly provides a definition of 'general' measures, thus the discussed notions are purely doctrinebased. They are largely based on the AG's opinions. See C-308/01 GIL Insurance Ltd and Others $v$ Commissioners of Customs and Excise [2004] ECR I-4777, Opinion of AG Geelhoed and C-241/94 France $v$ Commission of the European Communities (Kimberly Clark Sopalin) [1996] ECR I-4551, Opinion of AG Jacobs.

${ }^{26}$ Leigh Hancher, Tom Ottervanger and Piet-Jan Slot (eds), EC State Aids, 3rd Edition (Sweet \& Maxwell 2006) 53. See also Commission Notice on the application of the State Aid rules to measures relating to direct business taxation [1998] OJ C384/3.

27 T-55/99 CETM (n 11), para 39; T-152/99 HAMSA (n 16), para 156; T-210/01 British Aggregates Association v Commission of the European Communities [2006] ECR II-2789, para 105 .
} 
comparison. ${ }^{28}$ As per ECJ case law, such a comparison must be made with operators which are in a 'comparable legal and factual situation' in light of the objective pursued by the given State measure. ${ }^{29}$ Furthermore, this comparison must relate to an undertaking in the same Member State. ${ }^{30}$ It is not sufficient for a measure to be considered selective simply because it produces an advantage for an undertaking in one Member State which is not enjoyed by the operators in a corresponding position located in other EU states. ${ }^{31}$ It goes without saying that aid may not be compatible with the Internal Market if it solely seeks to establish parity with the situation in other Member States. ${ }^{32}$

Identification of a point of reference is especially tricky in the case of undertakings in a unique position vis-à-vis other market operators. ${ }^{33}$ This applies mainly to undertakings with special or exclusive rights or entrusted in operations of services of general economic interest. ${ }^{34}$ In all such cases there is no point of reference for comparison with other market players. ${ }^{35}$ The European Commission's (EC) decisions in the OTE and La Poste cases serve as examples. ${ }^{36}$ In both cases the EC held that the system of reference applicable to other undertakings could not be applied for the identification of advantage. Both entities, a tier-one telecommunications provider (OTE) and a public postal operator (La Poste), had obligations in terms of pension contributions which are unique and cannot be compared with the obligations of other undertakings in their respective countries. The EC decided to draw comparisons with the situation prevailing for these operators prior to implementation of the planned measures. ${ }^{37}$

${ }^{28}$ C-189/91 Petra Kirsammer-Hack v Nurhan Sidal [1993] ECR I-6185, Opinion of AG Darmon, para 58 - 61; C-353/95 Tiercé Ladbroke SA v Commission of the European Communities [1997] ECR I-7007, Opinion of AG Cosmas, para 30; C-88/03 Portugal v Commission of the European Communities (Azores) [2006] ECR I-7115, para 56.

${ }^{29}$ C-143/99 Adria Wien (n 11), para 41; C-409/00 Spain v Commission of the European Communities [2003] ECR I-1487, para 47; C-308/01 GIL Insurance (n 25), para 68; C-172/03 Heiser (n 17), para 40; C-88/03 Azores (n 27), para 54 and 56; T-233/04 Netherlands $v$ Commission of the European Communities [2008] ECR II-591, para 88 - 96.

${ }^{30} \mathrm{~T}-308 / 00$ Salzgitter AG v Commission of the European Communities [2004] ECR II-1933, para 81. This part was approved on appeal in C-408/04 P Commission of the European Communities v Salzgitter AG (Salzgitter II) [2008] ECR I-2767, para 109.

${ }^{31}$ Kelyn Bacon (ed), European Community Law of State Aid (OUP 2009), para 2.1112.

32 ibid.

33 Koen Van de Cateele and Mehdi Hocine, "'Favouring certain undertakings or the production of certain goods': Selectivity" in Wolfgang Mederer, Nicola Pesaresi and Marc Van Hoof (n 6) 252.

${ }^{34}$ See further discussion in Erika Szyszczak, The Regulation of the State in Competitive Markets in the EU (Hart

2007) 223; Jakub Kociubiński, 'Services of General Economic Interest - Towards a European Concept of Public Services' (2011) 1 WRLAE 49.

${ }^{35}$ Van de Cateele and Hocine (n 33) 252.

${ }^{36}$ Commission Decision of 10 May 2007 on State Aid C 2/06 (ex N 405/05) which Greece is planning to implement for the early voluntary retirement scheme of OTE [2008] OJ L243/7 and Commission Decision of 10 October 2007 on the State Aid implemented by France in connection with the reform of the arrangements for financing the retirement pensions of civil servants working for La Poste [2008] OJ L63/16.

${ }^{37}$ These decisions show a departure from the previous position expressed by the Commission in the PMU (Pari Mutuel Urbain) decision where it was argued that taking as a reference situation the prevailing change of the system would render impossible any change on taxation (93/625/EEC: Commission Decision of 22 September 1993 concerning aid granted by the 
To sum up, on a certain level of generality the concept in question consists of two elements - material and geographical. ${ }^{38}$ The geographical component is relatively easy to pinpoint, as a measure is selective if undertakings in a specific part of the territory of the Member State receive preferential treatment over other operators in the remainder of this territory. ${ }^{39}$ Material selectivity, on the other hand, encompasses all other forms of unequal treatment of undertakings by way of intervention of public authorities. ${ }^{40}$ This concept covers all measures addressed to certain categories of undertakings. Closer scrutiny of the selectivity concept reveals three main issues: First, whether measures applicable to a limited area may still be deemed 'general'; second, whether an 'apparently general' measure may have incidental selective effect; and third, whether the nature and scheme of the system may serve as a justification of unequal treatment. These will be further analysed.

\section{GEOGRAPHIC SELECTIVITY}

Practical application of the geographic selectivity criterion is relatively straightforward. The question has largely been settled in ECJ case law. Geographic or regional selectivity typically covers measures whose raison d'être is regional development. ${ }^{41}$ meaning measures designed to support undertakings willing to invest in a designated geographical area. ${ }^{42}$ The Court expressed the opinion that the criterion of selectivity in the geographic aspect relates to 'geographic location in a defined part of the territory of a Member State'. ${ }^{43}$ In other words, if a given measure does not apply to the whole territory of a Member State, it is in principle deemed to be selective. ${ }^{44}$

However, in the IRAP case the Commission stated that in the event a Member State assigns tax competences in a symmetric manner to all provinces/regions, the latter could serve as a yardstick for State Aid control

\footnotetext{
French Government to the Pari mutuel urbain (PMU) and to the racecourse undertakings [1993] OJ L300/21).

${ }^{38}$ Bartosh (n 19) 730.

${ }^{39}$ See inter alia Case C-88/03 Azores (n 28); Joined Cases C-428/06 to C-434/06 Unión General de Trabajadores de La Rioja (UGT-Rioja) and Others v Juntas Generales del Territorio Histórico de Vizcaya and Others [2008] ECR I-6747 and T-75/03 Banco Comercial dos Açores, SA v Commission of the European Communities [2009] ECR II-143.

${ }^{40}$ Bartosh (n 19) 730.

${ }^{41}$ Van de Cateele and Hocine (n 33) 258.

${ }^{42}$ See Case C-110/03 Belgium v Commission of the European Communities [2005] ECR I2801, para 58; Joined Cases T-269/99, T-271/99 and T-272/99 Territorio Histórico de Guipúzcoa - Diputación Foral de Guipúzcoa, Territorio Histórico de Álava - Diputación Foral de Álava and Territorio Histórico de Vizcaya - Diputación Foral de Vizcaya v Commission of the European Communities [2002] ECR II-4217, para 55 - 56; T-211/04 and T-215/04 Government of Gibraltar and United Kingdom of Great Britain and Northern Ireland v Commission of the European Communities [2008] II-3745

${ }^{43}$ Cases T-308/00 Salzgitter (n 30), para 38 and C-408/04 P Salzgitter II (n 30), para 109.

${ }^{44}$ Mariusz Popławski 'Charakter ulg i zwolnień podatkowych będących pomocą publiczną' (2005) 7 Monitor Podatkowy 33; Van de Cateele and Hocine (n 33) 258
} 
purposes. ${ }^{45}$ Further analysis of European Commission decisions and ECJ case law seem to show a departure from this line of reasoning. For instance, the Court held a tax incentive scheme for New Länder and Berlin to be State Aid purely on the basis of its limited territorial scope. ${ }^{46}$ The same was true in Commission decisions in Gibraltar and Azores. ${ }^{47}$ The EC held that the exercise of financial autonomy of the regions in question resulting from asymmetrical devolution of powers throughout the State can constitute State Aid if it leads to preferential tax rates over the rest of that State. ${ }^{48}$

The Commission position was nevertheless rejected by the ECJ. In its ruling in the Azores decision, the ECJ maintained that, in principle, the framework of reference may consist in a provincial/regional authority enjoying fiscal autonomy. ${ }^{49}$ The Court established a set of three cumulative criteria, the fulfilment of which would allow geographically limited measures not to be considered selective for State Aid control purposes. ${ }^{50}$ The first stage of scrutiny covers the nature of the fiscal autonomy a given province/region has. The infra-State authority must have, from a constitutional point of view, a political and legal status separate from the central government. ${ }^{51}$ Second, the authority in question must have procedural autonomy in the sense that no central government should have the possibility to intervene with regard to the content of a regional measure. ${ }^{52}$ Third, the infra-State body must enjoy financial autonomy. Any reduction of tax in the region must not by offset by financial inputs from the central government or other regions. ${ }^{53}$ In other words, the ECJ stated that the authority in question must not only have the powers to adopt a measure but must also face political and financial consequences of such a step. ${ }^{54}$

The same institutional, procedural and financial autonomy test was applied in the subsequent UGT-Rioja case. ${ }^{55}$ The subject of scrutiny was the taxation rate established by Basque regional authorities, which was lower

\footnotetext{
${ }^{45}$ Potenziamento delle aree sottoutilizzate (Agevolazione per nuove assunzioni - Deduzioni IRAP) (Case N 198/2005) Commission Decision of 07 December 2005 - Notice [2005] OJ $\mathrm{C} 42 / 2$.

${ }^{46}$ C-156/98 Federal Republic of Germany $v$ Commission of the European Communities [2000] ECR I-6857. See also previous Commission Decision 98/476/EC of 21 January 1998 on tax concessions under Paragraph 52(8) of the German Income Tax Act (the Einkommensteuergesetz) [1998] L212/50. The widely used term 'New Länder' refers to the territory of the former GDR (German Democratic Republic) after reunification.

47 Government of Gibraltar Corporation Tax Reform (Case C 66/2002) Commission Decision of 30 March 2004 [2005] OJ L85/1 and Commission Decision of 11 December 2002 on the part of the scheme adapting the national tax system to the specific characteristics of the Autonomous Region of the Azores which concerns reductions in the rates of income and corporation tax (Case C 35/2002 Régime fiscal des Açores) [2003] OJ L150/52.

48 ibid.

${ }^{49}$ Jan A Winter 'Case C-88/03, Portuguese Republic v. Commission annotation' (2008) 45

CMLR 183

${ }^{50}$ C-88/03 Azores (n 28); William Lindsay-Poulsen 'Regional Autonomy, Geographic Selectivity and Fiscal Aid: Between “The Rock” and a Hard Place' [2008] 29 ECLR 43.

${ }^{51} \mathrm{ibid}$, paras $54-56$

52 ibid.

${ }^{53}$ ibid, paras 54 and 64.

${ }^{54}$ Winter (n 49) 183.

${ }^{55}$ Joined Cases C-428/06 to C-434/06 UGT Rioja (n 39).
} 
than in the rest of Spain. ${ }^{56}$ As it was only a preliminary ruling, the ultimate decision on the scheme was left to the national court, but in its sentence the ECJ indicated that the institutional and procedural criteria were fulfilled. ${ }^{57}$ In respect to the third condition of financial autonomy, the Court shared Advocate General Julianne Kokott's opinion that Basque provinces have a 'sufficiently autonomous economy'. ${ }^{58}$ The ECJ went further and concluded that the mere fact of financial transfers between central State and relevant regional bodies did not in itself rule out financial autonomy. The key question is rather the link between lowering of the tax rate and the transfer. In other words, the transfer in question must not compensate the regional authority for the consequences of a given tax measure. ${ }^{59}$ It seems that the Azores judgment provides a useful, although not totally objective, tool for assessing whether territorially limited measures could be deemed selective. ${ }^{60}$ The test would be of particular importance in the case of those States which devolve particular competences in an asymmetrical manner, that is, to some but not all of their provinces/regions. ${ }^{61}$

\section{MATERIAL Selectivity}

One of the striking features of the concept of material selectivity in the ECJ case law is its broad scope. The basic material selectivity test is intended to ascertain whether a measure in question provides for unequal treatment of at least two groups of undertakings that prima facie should be treated equally. ${ }^{62}$ It goes without saying that the mere fact that a measure applies without distinction to a clearly defined group of operators is not yet sufficient to consider it as a general measure. ${ }^{63}$ The ECJ case law on this subject contains contradictions and uncertainties. This may be due to fact that such a broad concept blurs the dividing line between illicit State Aid and the general economic policy of a Member State. ${ }^{64}$

Material selectivity may be established by law or in fact. ${ }^{65}$ As point of departure, one must recall that the concept of State Aid and its components is

\footnotetext{
${ }^{56}$ The principle of autonomy of the Regions is embedded in the Consitution of Spain (Articles 143 to 158 ).

57 Joined Cases C-428/06 to C-434/06 UGT Rioja (n 39), paras 86 - 87 (institutional autonomy) and 95 - 110 (procedural autonomy)

58 ibid, Opinion of AG Kokott, para 116.

59 Joined Cases C-428/06 to C-434/06 UGT Rioja (n 39), para 123 - 140.

${ }^{60}$ Bartłomiej Kurcz 'How Selective is Selectivity' (2007) 66 CLJ 313; Phaedon Nicolaides 'Fiscal State Aid in the EU: The Limits of Tax Autonomy' (2004) 27 World Competition 392; Saturnina Moreno Gonzalez 'Regional Fiscal Autonomy from a State Aid Perspective: The ECJ's Judgment in Portugal v. Commission' (2007) 47 European Taxation 328.

${ }^{61}$ Joined Cases T-211/04 and T-215/04 Gibraltar (n 42).

${ }^{62}$ Bartosch (n 19) 731. The second step that follows is assessment of whether the selective nature of the measure in question could be justified by the nature or general scheme of the system. This issue will be discussed further in the next paragraph.

${ }^{63}$ Van de Cateele and Hocine (n 33) 253.

${ }^{64}$ Anna Nykiel-Mateo, Pomoc państwa a ogólne środki interwencji w europejskim prawie wspólnotowym (Oficyna Wolters Kluwer business 2009) 186; C-241/94 Kimberly Clark Sopalin (n 25), Opinion of AG Jacobs, para 30.

${ }^{65}$ Vittorio Di Bucci 'Direct Taxation - State Aid in Form of Fiscal Measures' in Sánchez Rydelski (n 5) 79. See also Case C-143/99 Adria Wien (n 11), para 41.
} 
an objective one. ${ }^{66}$ In other words, the legal concept should be interpreted on the basis of objective factors, not its 'aims or causes' without any room for a State's discretion. ${ }^{67}$ Following that line of reasoning the Court of First Instance (CFI) in its Álava ruling considered that a tax credit to investments over a certain threshold (approx. $€ 15$ million) is de facto selective as it applies to undertakings with significant financial resources. ${ }^{68}$ The same principle was recognized by the Court in its GEMO judgment. ${ }^{69}$ The ECJ held that a measure that could incidentally benefit individuals cannot be regarded as general. $^{70}$

A good illustration of the need for an in-depth analysis is provided by the European Commission decision concerning reduction of social contributions for women employees. ${ }^{71}$ The EC made its assumption on statistics stating that the percentage of female workers was especially high (approx. 70 percent) in the textile industry, and therefore the measure in question was selective as it favoured this sector. ${ }^{72}$ The question remains open of whether the Commission's line of inquiry in the aforementioned decision is valid in terms of its methodology. An interesting case study on the issue of de facto selectivity is also provided by the EC decision on tax advantages granted to high-earning foreign experts in Denmark. At first (in 1992) the Commission came to the conclusion that the measure in question was de facto selective since it affected only a limited number of undertakings. ${ }^{73}$ After the government of Denmark provided data showing that the measure was indeed benefitting operators of all sizes in all sectors (in 1999), the EC reconsidered its previous decision, even though the provided data pointed to a concentration of aid in large undertakings operating in certain sectors. Nevertheless, the Commission stated that this was not sufficient to consider the measure selective as this was mainly due to the specifics of the sector. ${ }^{74}$

Furthermore, even apparently general measures discretionally applied by domestic public authorities which could lead to discriminatory outcomes will likely be subject to the Article 107(1) TFEU prohibition. ${ }^{75}$ In other words, when a public body in a Member State granting a benefit or advantage has discretional powers allowing it to determine the recipients or the terms of

\footnotetext{
66 Supra (n 16) 3.

${ }^{67}$ ibid. See also Case 173/73 Italy v Commission (n 9), para 27.

${ }^{68}$ Joined Cases T-92/00 and T-103/00 Territorio Histórico de Alava - Diputación Foral de Alava Ramondín, SA and Ramondín Cápsulas, SA v Commission of the European Communities [2002] ECR II-1385, para 39.

${ }^{69}$ Case C-126/01 Ministère de l'Économie, des Finances et de l'Industrie v GEMO SA [2003] ECR I-13769.

70 Similar reasoning see Commission Decision of 17 February 2003 on the State Aid implemented by the Netherlands for international financing activities (Case N 51/2001) [2003] OJ L180/52.

${ }^{71}$ 80/932/EEC: Commission Decision of 15 September 1980 concerning the partial takingover by the State of employers' contributions to sickness insurance schemes in Italy [1980] OJ L264/28.

72 ibid.

${ }^{73}$ Special flat rate of income tax for expatriate scientist and executives (Case N 69/1991) Notice [1992] OJ C184/13. The measure was nevertheless approved under Article 107(3)(c) TFEU.

${ }^{74}$ Modification of a scheme for flat-rate taxation for experts recruited abroad (Case N 49/1999) Commission Decision of 03 May 2000 - Notice [2000] OJ C264/4.

${ }^{75}$ Nicolaides (n 60) 393.
} 
the granted measure, it cannot be considered general. ${ }^{76}$ However, if the role of the relevant public body is limited to verifying objective criteria, then in the absence of discretionary powers a measure can be deemed general. ${ }^{77}$ This line of reasoning was followed by the Commission in the G.I.E. fiscaux decision. ${ }^{78}$ The EC considered that the granting of a tax advantage was related to the realisation of investments having 'significant economic and social interest both in general and from an employment standpoint in particular'. ${ }^{79}$ Such vaguely formulated conditions lead to the conclusion that the measure in question offered the State's authorities a wide margin of discretion. ${ }^{80}$

In a nutshell, the above examples show that de facto selectivity is primarily linked to the imposition by public authorities (intentionally or not) of conditions or barriers that limit access to the benefits from a given measure to certain categories of undertakings, rather than the existence of data showing concentration in certain sectors. ${ }^{81}$ Consequently, the EC considered aid granted to certain categories of undertakings (SMEs, public, manufacturing etc.) in principle fulfil the selectivity criterion (individual aid). ${ }^{82}$ In the same vein, sectoral aids are selective irrespective of whether the relevant measure is applied to all operators in that sector. ${ }^{83}$ Similar considerations operate for measures only applying to undertakings formed as

\footnotetext{
${ }^{76}$ Case C-200/97 Ecotrade (n 11); Joined Cases T-127/99, T-129/99 and T-148/99 Territorio Histórico de Álava Diputación Foral de Álava, Comunidad Autónoma del Pais Vasco and Gasteizko Industria Lurra, SA and Daewoo Electronics Manufacturing España, SA v Commission of the European Communities [2002] ECR II-1275; 2003/501/EC: Commission Decision of 16 October 2002 on the State Aid scheme C 49/2001 (ex NN 46/2000) Coordination Centres - implemented by Luxembourg [2003] OJ L170/20.

${ }^{77}$ Van de Cateele and Hocine (n 33) 257; Popławski (n 44) 33. See for example decisions Partially accelerated depreciation for R\&D laboratories (Case N 18/97) Commission Decision of 11 May 1999 - Notice [1999] OJ C225/3; Réduction de cotisations patronales de sécurité sociale en cas d'application d'une durée de travail hebdomadaire de 38 heures et en cas de réduction du temps de travail (Case N 232/2001) Commission Decision of 03 July 2001 - Notice [2001] C268/10; Subsidies for investments in knowledge-infrastructure (BSIK) (Case N 291/2001) Commision Decision of 07 August 2002 [2003] OJ C18/37.

${ }^{78}$ Commission Decision of 20 December 2006 on the aid scheme implemented by France under Article 39 CA of the General Tax Code - State Aid C 46/2004 (ex NN 65/2004) G.I.E. fiscaux [2007] OJ L 112/41.

${ }^{79}$ ibid, para 12.

${ }^{80}$ ibid, para 20, $122-124$.

${ }^{81}$ Bartłomiej Kurcz and Dimitri Vallindas 'Can General Measures Be Selective?: Some Thoughts on the Interpretation of a State Aid Definition' (2008) 45 CMLR 159 and Van de Cateele and Hocine (n 33) 257. See also next paragraph for further discussion.

${ }^{82}$ Cases C-200/97 Ecotrade (n 11); C-143/99 Adria Wien (n 11); T-55/99 CETM (n 11); Joined Cases T-127/99, T-129/99 Alava (n 75). See also decision 2003/755/EC: Commission Decision of 17 February 2003 on the aid scheme implemented by Belgium for coordination centres established in Belgium [2003] OJ L282/25 later overturned on grounds of breach of the legitimate expectation principle in Joined Cases C-182/03 and C-217/03 Belgium and Forum 187 ASBL v Commission of the European Communities [2003] ECR I-6887. See also decisions Commission Decision of 22 June 2005 on the measure implemented by Italy for professional sports clubs (Case C 70/2003) Decreto Salva Calcio [2006] OJ L353/16; Commission Decision of 26 May 2010 concerning State Aid in the form of a tax settlement agreement implemented by Belgium in favour of Umicore SA (formerly Union Minière SA) (State Aid C 76/03 (ex NN 69/03)) [2011] OJ L122/76.

${ }^{83}$ Case 173/73 Italy $v$ Commission (n 9) and 002/581/EC: Commission Decision of 11 December 2001 on the tax measures for banks and banking foundations implemented by Italy [2002] OJ L184/2.
} 
from a certain date. ${ }^{84}$ The same is true in the case of aid for exports, even if these measures are potentially applicable to all domestic undertakings. ${ }^{85}$ Measures applied on an experimental basis to certain undertakings are also deemed to be selective irrespective of whether they are intended to be applied to every industry in all sectors at a later time ${ }^{86}$ Despite the objective nature of the State Aid concept, it is not infrequent for the Commission to take into account intentions of the public authorities granting the aid, as inferred from the relevant parliamentary debate reports, statements of government officials or official press releases. ${ }^{87}$

\section{SELECTIVITY AND GENERAL SCHEME OF THE SYSTEM}

In order to justify a measure that would otherwise fall under the Article 107(1) TFEU prohibition the Court has coined the elaborate notion of 'the nature of the general scheme' of the system in question. ${ }^{88}$ Sometimes this justification has also been referred to as the 'nature or structure' or 'logic' of the system. ${ }^{89}$ The core of this justification is that given measures are not subject to the exemptions set out in Article 107(2) and (3) TFEU, but nevertheless are regarded as acceptable even if they are policy-driven. ${ }^{90}$ This justification applies almost exclusively to tax measures. ${ }^{91}$

\footnotetext{
${ }^{84}$ Decisions 2002/540/EC: Commission Decision of 11 July 2001 on the State Aid scheme applied by Spain to certain newly established firms in Guipúzcoa (Spain) [2002] L 174/31 and 2006/261/EC: Commission Decision of 16 March 2005 on aid scheme C 8/2004 (ex NN 164/2003) implemented by Italy in favour of newly listed companies [2006] OJ L94/42.

${ }^{85}$ Cases 11/69 Commission of the European Communities v France [1969] ECR 523 and 57/86 Greece v Commission of the European Communities [1988] ECR 2855, para 8.

${ }^{86}$ 97/811/EC: Commission Decision of 9 April 1997 concerning aid granted by France to the textile, clothing, leather and footwear industries [1997] OJ L334/25, para 7.

${ }^{87}$ Cases C-169/84 Société CdF Chimie azote et fertilisants SA and Société chimique de la Grande Paroisse SA v Commission of the Europan Communities [1990] ECR I-3083 and C148/04 Unicredito Italiano SpA v Agenzia delle Entrate, Ufficio Genova 1 [2005] ECR I11137.

${ }^{88}$ Cases C-173/73 Italy v Commission (n 9), para 15; C-75/97 Maribel bis/ter (n 17), para 39; C-251/97 France v Commission of the European Communities [1999] ECR I-6639, para 36; C-143/99 Adria Wien (n 11), para 42; C-351/98 Spain v Commission of the European Communities (Spanish Trucks I) [2002] ECR I-8031, para 42; Joined Cases T-269/99, T271/99 and T-272/99 Vizcaya (n 42), para 60; T-346/99 to T-348/99 Territorio Histórico de Álava - Diputación Foral de Álava, Territorio Histórico de Guipúzcoa - Diputación Foral de Guipúzcoa and Territorio Histórico de Vizcaya - Diputación Foral de Vizcaya $v$ Commission of the European Communities [2002] ECR II-4259, para 58; C-159/01 Netherlands $v$ Commission of the European Communities [2004] ECR I-4461, para 24 and T-210/02 British Aggregates Association v Commission of the European Communities [2006] ECR II-2789, para 107.

${ }^{89}$ Cases C-353/95 Tiercé Ladbroke (n 28), para 35; C-6/97 Italy v Commmission of the European Communities [1999] ECR I-2981, Opinion of AG Ruiz-Jarabo, para 27; Case T55/99 CETM (n 11), para 52; Joined Cases T-127/99, T-129/99 and T-148/99 Álava (n 75), para 163; C-53/00 Ferring SA p. Agence centrale des organismes de sécurité sociale (ACOSS), [2001] ECR I-9067, para 17; C-409/00 Spain v Commission of the European Communities (Spanish Trucks II) [2003] ECR I-1487, para 52; C-172/03 Heiser (n 17), Opinion of AG Tizzano, para 47 and Case C-222/04 Ministero dell'Economia e delle Finanze. v. Cassa di Risparmio di Firenze SpA and Others [2006] ECR I-289, para 137.

${ }^{90}$ Kurcz and Vallindas (n 80) 170.

${ }^{91}$ Bacon (n 31), para 2.127; Nykiel-Mateo (n 64) 205.
} 
Although the concept of 'the general scheme of the system' was established in early case law (1974), until recently it has offered limited guidance in regard to clarification of its application. ${ }^{92}$ The test of whether a measure can be justified on the aforementioned grounds relates to the internal functioning of the system and not to the external objectives assigned to it. ${ }^{93} \mathrm{It}$ is thus not sufficient to claim that a selective measure is justified by the nature of the system, but it is necessary to support such a claim by specific and detailed arguments on the facts. ${ }^{94}$ This stems from the rule that every exemption has to be interpreted narrowly. ${ }^{95}$ Naturally, in such situations the burden of proof rests entirely on the Member States. ${ }^{96}$

The point of departure in assessing whether a measure is consistent with the 'logic' of the system is the identification of a relevant system. ${ }^{97}$ Basically, the benchmark should pit the generality of undertakings against which the measure in question may be measured. ${ }^{98}$ This measure will be considered aid when an exemption - preferential treatment - is created for certain categories of undertakings deviating from a rule previously applicable to all operators. ${ }^{99}$ For example, in the Municipalizzate decision the EC held that the selective exemption of capital duty was justifiable on grounds of ensuring neutrality of tax system. ${ }^{100}$ The system in question concerns the transformation of public companies into joint stock companies and did not entail the creation of 'added value' in the form of capital or production, and therefore was considered as justified. ${ }^{101}$ Similarly, in GIL Insurance different rates of IPT (Insurance Premium Tax) were justified on the basis of deterring tax avoidance. ${ }^{102}$

While most of the cases in which 'the nature or general scheme of the system' were scrutinized were rejected of the principle on facts, the analysis of more recent case law reveals a more lenient approach to the issue at hand. The acknowledgment of objectives pursued by a Member State in the assessment of whether a measure in question may grant a selective advantage

\footnotetext{
92 ibid; Christos Golfinopoulos 'Concept of Selectivity Criterion in State Aid Definition Following Adria-Wien Judgment - Measures Justified by the "Nature or General Scheme of a System"' (2003) 24 ECLR 544. See also C-83/98 P Ladbroke, Opinion of AG Fennelly, para 19.

${ }_{93}$ Van de Cateele and Hocine (n 33) 260.

${ }^{94}$ C-83/98 P Ladbroke, Opinion of AG Fennelly, para 26.

95 Joined Cases T-127/99, T-129/99 and T-148/99 Álava (n 75), para 250.

${ }^{96}$ Case C-6/97 Italy v Commmission (n 88), Opinion of AG Ruiz-Jarabo, para 27; Case C159/01 Netherlands $v$ Commission (n 87), paras $43-46$; C-83/03 Azores (n 28), Opinion of AG Geelhoed, para 75.

${ }^{97}$ Case T-55/99 CETM (n 11), para 53.

${ }^{98}$ Golfinopoulos (n 91) 547; Nicolaides (n 60) 377. Only when the right benchmark rate is determined is it possible to assess whether the measure follows from the logic of the system. ${ }^{99}$ It is especially difficult in case of systems which from their onset distinguish between certain categories of undertakings. See C-143/99 Adria Wien (n 11), Opinion of AG Mischo, para 41 and 42. See also Conor Quigley 'The Notion of a State Aid in the EEC' (1988) 13 ELRev 245; Kurcz and Vallindas (n 80) 171 and Nicolaides, Kekelekis and Buyskes (n 24) 25 .

100 2003/193/EC: Commission Decision of 5 June 2002 on State Aid granted by Italy in the form of tax exemptions and subsidised loans to public utilities with a majority public capital holding (Municipalizzate) [2003] OJ L77/21.

101 ibid, para $51-64$.

${ }^{102}$ Case C-308/01 GIL Insurance (n 28), para 73 - 78. See also Leendert A Geelohoed 'The Demarcation of State Aid and Regulatory Charges' (2005) 3 EStAL 402.
} 
has been fully endorsed by the Court in the British Aggregates and Dutch NOx rulings. although the former was finally overturned. ${ }^{103}$ It is worth mentioning that these judgments concern both fiscal and non-fiscal measures, which raises the question of whether they should be assessed on the basis of the same criteria. ${ }^{104}$

In British Aggregates the CFI considerd an aggregates levy (AGL) to be consistent with environmental goals. The Court of First Instance, following the Commission's reasoning, concluded that an exemption from the scope of the aggregate levy of certain aggregates having indeed a better environmental impact than those subject to the levy and thus measure was considered 'reasonably justified'. ${ }^{105}$ Given the absence of harmonization of environmental policies, referring to Article 11 TFEU the CFI held that Member States were deemed to be 'free, in balancing the various interests involved, to set their priorities as regards the protection of the environment and, as a result, to determine which goods or services they are to decide to subject to an environmental levy'. ${ }^{106}$ After referring the case back to the General Court (formerly CFI), the previous judgment was eventually overturned. ${ }^{107}$ On appeal, the General Court considered that the Commission failed to correctly assess 'normal' taxation under the measure in question, and thus the comparison of factual and legal situations of undertakings involved gave an erroneous result. ${ }^{108}$ Even though the General Court found the EC reasoning flawed, it did not in principle reject the telos of the original judgment.

The latter case, Dutch NOx, concerned a system of emissions trading. ${ }^{109}$ Under the system, certain undertakings were allowed to freely trade emission certificates on the market. Hence, any operator could be within acceptable emission thresholds either by investments in modernization of its facilities or through purchasing emission certificates from another undertaking. In its ruling, the CFI - relying on its previous Adria-Wien judgment - focused on the assessment of whether a limited group of undertakings was benefitting from the measure in question while others were not, and if these groups were in 'a comparable factual and legal situation'. ${ }^{110}$ This was answered negatively, as the given scheme was limited to those large undertakings which were liable to pay fines in case they exceeded emission levels. Smaller operators under the measure could not be fined in an analogous situation, thus the situation of the two groups were not comparable. ${ }^{111}$ The scheme was therefore not regarded as prima facie selective. ${ }^{112}$ The ruling was fully upheld in appeal. ${ }^{113}$

\footnotetext{
${ }^{103}$ Cases T-210/02 British Aggregates (n 87) and T-233/04 Netherlands $v$ Commission of the European Communities (Dutch NOx) [2008] II-591.

${ }^{104}$ Bartosh (n 19) 735.

${ }^{105}$ Cases T-210/02 British Aggregates (n 87) referred back to the General Court on the ground of errors in law in Case C-487/06 P British Aggregates Association v Commission of the European Communities and United Kingdom [2008] ECR I-10515.

106 ibid, para 115.

${ }^{107}$ Case T-210/02 RENV British Aggregates Association v European Commission nyr.

108 ibid, para $50-61$.

${ }^{109}$ Case T-233/04 Dutch NOx (n 102).

110 ibid, para 80. See also Case C-143/99 Adria Wien (n 11), para 41.

111 ibid, para 90.

112 ibid, para 99 and 100.

${ }^{113}$ Case C-279/08 P European Commission v Netherlands (Dutch NOx II) [2011] ECR 00.
} 
The principle of justification by 'the nature and the scheme of the system' is of particular relevance in the field of indirect taxation. Of course, the Commission's notice on the application of State Aid rules to measures relating to direct business taxation do not address this issue explicitly, but further analysis shows that its findings are well-suited for application here. ${ }^{114}$ Contrary to direct taxation, which targets revenues, indirect taxation targets production. ${ }^{115}$ Furthermore, a certain harmonization in this field has been achieved. ${ }^{116}$ This area of financial measures has been the subject of the Court's analysis in the Idéal tourisme case. ${ }^{117}$ The system under which the full VAT rate was applicable to coach transport while air transport was VAT exempt was found to be discriminatory on the grounds that there was direct competition between undertakings in these sectors. ${ }^{118}$ This reasoning seems dubious as it could be argued that services in these sectors are not entirely comparable. In principle, however, VAT is considered neutral in terms of competition (VAT charges are not counted as costs). ${ }^{119}$ Therefore, setting aside abnormal market conditions, State Aid regulations are largely inappropriate for tackling this issue. ${ }^{120}$ Analysis of all the above cases as well as subsequent case law therefore leads to the conclusion that the concept of 'the nature and general scheme of the system' applies in two situations, when it is necessary for the proper functioning of the system or when they reflect the objectives pursued by the State measure. ${ }^{121}$ The question remains open how susceptible this concept is to potential abuses. ${ }^{122}$

\section{CONCLUDING REMARKS}

\footnotetext{
${ }^{114}$ Commission Notice on the application of the State Aid rules to measures relating to direct business taxation [1998] OJ C384/3. See also Commission Report on the implementation of the Commission notice on the application of the State Aid rules to measures relating to direct business taxation C(2004)434, para 71.

115 Such a rigid, dogmatic statement, while true in principle is overly simplified if one goes into detailed analysis of a measure. See Wolfgang Schön, 'Taxation and State Aid Law in the European Union' (1999) 36 CMLR 920.

${ }^{116}$ See Council Directive 2006/112/EC of 28 November 2006 on the common system of value added tax [2006] OJ L347/1.

${ }^{117}$ Case C-36/99 Idéal tourisme SA v Belgian State [2000] ECR I-6049.

118 The Court held that undertakings in the sectors concerned were in direct competition in services on distances between 300 and $3000 \mathrm{~km}$.

119 Case T-68/03 Olympiaki Aeroporia Ypiresies AEv Commission of the European Communities [2007] ECR II-2911, para 361.

${ }^{120}$ Geelhoed (n 98) 402; Van de Cateele and Hocine (n 33) 264; Nicolaides (n 60) 383. See also Cases C-308/01 GIL Insurance (n 28); T-210/02 British Aggregates (n 87). For the notion of 'exceptional burden' see Case C-128/92 H. J. Banks \& Co. Ltd v British Coal Corporation [1994] ECR I-1209.

${ }^{121}$ See subsequent case law for further application of the discussed principle: Joined Cases T-127/99, T-129/99 and T-148/99 Álava (n 75), para 164; T-92/00 and T-103/00 Ramondín (n 68), para 60 and decisions Tax exemptions for certain energy intensive processes (Case $\mathrm{N}$ 820/2006) Commission Decision of 07 February 2007 - Notice [2007] OJ C80/1; Zero tariff for green electricity (Case NN 30b/2000) Commission Decision of 28 November 2001 Notice [2002] C30/12; Environmental protection - Netherlands (Case N 678/2001) Commission Decision of 18 October 2001 - Notice [2002] C30/12; 2002/676/EC,ECSC: Commission Decision of 3 April 2002 on the dual-use exemption which the United Kingdom is planning to implement under the Climate Change Levy and the extended exemption for certain competing processes [2002] OJ L229/15; Cuneo fiscale (tax wedge) (Case N 184/2007) Commission Decision of 12 September 2007 - Notice [2007] C245/1; Irish Holding Company Regime (N 354/2004) Commission Decision of 22 November 2004 Notice [2005] OJ C131/10.

${ }^{122}$ Kurcz and Vallindas (n 80) 173.
} 
The distinction between general and selective measures is subject to considerable controversy and continues to fuel quite a large debate. The key issue is the limes between the freedom Member States should enjoy when it comes to the pursuit of their various policies and State Aid regulations. The question is thus how to find a happy medium between safeguarding an effective level of Internal Market competition on the one hand, and on the other preventing the Commission from second-guessing measures States devise in order to pursue their legitimate policy goals. The selectivity criterion seeks to resolve this conundrum.

Unfortunately, the case law shows that the practical application of selectivity criterion is rather ambiguous. In this respect, the 'objective-based approach' seems especially vague. At the same time it is glaringly obvious that State Aid control would be deprived of its effectiveness if Member States were allowed to use their policy goals as a 'shield' which would hide the material selectivity of a measure. The problem, it seems, lies at the very nature of the selectivity criterion. One cannot avoid a certain level of discretionary or even arbitrary components in an attempt to strike the right balance between 'bad' and 'good' policy objectives. To put it simply - there is no clear-cut here.

Furthermore, tension between the aforementioned objective-based and effect-based approachs is also unavoidable (in both their geographical and material aspects). If the latter is uniformly applied, there would be hardly any measure that could escape from being classified as selective. That would enlarge the scope of the selectivity criterion to an unacceptable level of comparison of the divergent factual and legal circumstances that exist in individual Member States. On the other hand, the former is especially prone to abuses. Actual analysis will of course feature a mix of the two approaches. This is by no means an easy task, and such analysis will surely cause considerable controversy. Yet as Andreas Bartosch excellently pointed out, " $(. .$.$) the fear that a task may be difficult to perform should not stop us from$ taking it on". ${ }^{123}$

${ }^{123}$ Andreas Bartosch 'The Concept of Selectivity?' in Szyszczak (n 18) 190. 